\title{
Motivation to Write: Conversations with Emergent Writers
}

\author{
Caroline Barratt-Pugh $^{1}$ [ $\cdot$ Amelia Ruscoe $^{1} \cdot$ Janet Fellowes $^{1}$
}

Published online: 9 May 2020

(c) The Author(s) 2020

\begin{abstract}
This article describes the processes and outcomes of a research project exploring children's motivation to write, undertaken by four pre-primary teachers in Western Australia. The teachers adopted a sociocultural theoretical framework using child centred participatory methodology, in which 109 children aged between five and six years shared their views of writing in conversation with their teacher. Thematic analysis in conjunction with statistical analysis indicated that the majority of children were motivated to write. They had a positive attitude towards writing, evidenced by their self-efficacy and were developing aspects of self-determination evidenced by their sense of ownership and control of the codes of writing. They had some understanding of the value of writing as a means of supporting reading and securing a positive future, thus enhancing their motivation to write. However, a small group of children indicated that they did not like writing, found writing hard, and did not know how or what to write. In addition, few children mentioned writing as a means of communication. The absence of purpose and audience in the children's responses, was partly explained by the teachers' focus on the codes of writing, potentially impacting on children's motivation. This prompted the teachers to re-conceptualise their writing program in ways that engaged children in authentic writing tasks, while continuing to scaffold their understanding of the codes of writing. This collaborative approach to research, in ways that privilege children's voices, has implications for informing pedagogy across a range of early childhood contexts and curriculum areas.
\end{abstract}

Keywords Motivation · Emergent writing · Children's voices $\cdot$ Teacher reflection $\cdot$ Purpose and audience

\section{Introduction}

This article describes a research project undertaken by four early childhood teachers, exploring the motivation of emergent writers. During the past two decades, an increasing number of studies have identified motivation as a key component of learning literacy which is mediated through the context in which learning occurs (Bruning and Kauffman 2016; Magnifico 2010; Mata 2011; Nolen 2007). This research draws on a sociocultural theoretical framework which suggests that there is a powerful relationship between teacher pedagogy and practice and children's motivation to learn literacy (Bingham et al. 2017; Bogner et al. 2002). The concept of motivation is complex and multifaceted involving many different but interrelated components, drawn from different theoretical frameworks (Nolen 2007; Troia et al.

Caroline Barratt-Pugh

c.barratt_pugh@ecu.edu.au

1 School of Education, Edith Cowan University, Mt. Lawley Campus, Bradford Street, Mt. Lawley, WA 6050, Australia
2012; Schunk et al. 2008). In relation to writing, the most frequently used motivation construct to explore writing is self-efficacy (Troia et al. 2012). Self-efficacy includes an individual's perception of themselves as a writer, their persistence when a writing task becomes challenging, and utilization of productive strategies (Boscolo and Hidi 2007; Pajares and Valiante 2006). Self-efficacy is closely aligned to self-determination theory in which an individual's sense of choice, ownership and control of the text influence their motivation (Magnifico 2010; Marinak et al. 2012; Putman and Walker 2010). These two constructs, self-efficacy and self-determination are mediated through the individual's level of interest and enjoyment, which relates to the situational context in which learning occurs, the link to home and community writing experiences (Mackenzie and Petriwskyj 2017), and include for example, characteristics of a writing task (Hidi and Renninger 2006). These aspects of motivation are central to early childhood learning and development in general, and to writing in particular, thus providing a sound methodological framework for the investigation of 
motivation in emergent writers within a sociocultural theoretical framework.

\section{Research Context}

The Association for Independent Schools, Western Australia (AISWA), invited early childhood educators in Western Australia to take part in a program of professional learning across a year. This professional learning aimed to grow the expertise of early childhood teachers in the field of emergent writing and in turn, enhance the learning experience of emergent writers in their schools. The professional learning program was designed and facilitated in partnership with early childhood literacy academics from Edith Cowan University (ECU), in Western Australia, based on a collaborative reflective practice model of learning (Brown and Englehardt 2016; Opfer and Pedder 2011). Twenty-four early childhood teachers attended the professional learning program to explore an aspect of emergent writing through planning, implementing and evaluating a research project in their classroom context.

This article is about the research undertaken by four preprimary teachers who identified a common concern about children's motivation to write at the beginning of the professional learning program. In Western Australia, pre-primary is the first full-time compulsory year of schooling which children begin when they turn five by the end of June. There were a small group of children that the four teachers were particularly worried about in relation to their apparent lack of motivation, in addition, they identified a "general lack of enthusiasm" for writing by many other children. The teachers' perceptions were based on two sets of evidence collected at the beginning of the professional learning program. The evidence included observations of the children engaged in writing and samples of writing. The teachers shared the data with each other and although the children's attitudes and practices varied across time and to some extent in relation to the writing task, they jointly identified a continuum of attitudes and practices towards writing, ranging from positive to negative.

Their initial concerns about a small group of children, which mainly consisted of boys, were confirmed, revealing an apparent lack of motivation. This was evidenced by reluctance to begin and lack of perseverance in completing writing tasks, the apparent carelessness and desire to finish a task quickly, sometimes resulting in "scrappy" work which was often discarded in frustration. In addition, some of these children did not want to share, display or take their writing home. The teachers noted that although not reluctant to write, there were a substantial number of children that exhibited some of these characteristics, often in relation to the purpose of the writing task, and level of support provided.
One teacher also mentioned that some children appeared to be "bored" or "lazy", suggesting that they were complacent about learning to write. At the other end of the continuum a small group of children were mainly enthusiastic about writing and engaged with determination and perseverance.

The teachers felt that the data provided enough evidence to warrant their concerns. They expressed anxiety that children as young as five appeared to take little enjoyment in learning to write, and already had a negative attitude toward writing. On the basis of their findings the four teachers decided to make motivation to write the focus of their research.

\section{Literature Review}

\section{Children's Attitudes Towards Writing}

Children's attitudes towards writing evolve from their beliefs about themselves as writers, which is a crucial component of motivation to write (Bruning and Kauffman 2016; Marinak et al. 2012; Mata 2011; Nolen 2007). The concept of belief is derived from self-efficacy theory (Bandura 1977), which relates to an individual's belief about their ability to complete a task or be successful in specific situations. In writing, children develop self-efficacy through engaging in texts that are meaningful to them, align with their development and are self-satisfying (Grainger et al. 2003). Emergent writers who experience writing in this way learn to expect to be successful at writing, therefore fuelling motivation to engage in writing (Mata 2011). Pajares and Valiante (2006) propose that a confident approach to writing tasks is essential to skill improvement and Bruning and Kauffman (2016) suggest that the relationship between writing efficacy and writing skill is reciprocal, arguing that the advantages of promoting skill development for high efficacy writers include "lower anxiety, greater persistence, and higher toleration for frustration in writing tasks" (p. 28). Conversely, a fear of making mistakes may be an indication that there are expectations communicated to children about what is an acceptable attempt at writing, and that, for some children, these are perceived as unobtainable, creating a diminished sense of motivation (Rueda 2011).

\section{Children's Sense of Ownership and Control of Writing}

Research suggests that having a sense of ownership and control, or agency, is also integral to motivation to write (Mata 2011). These constructs are part of self-determination theory, which include the learner's sense of competence, connection and autonomy (Wigfield et al. 2015). Children's motivation to write becomes intrinsic when given choice 
and ownership over the content, process and outcome of their writing, and freedom to create texts about what they see as important (Kissel and Miller 2015; Magnifico 2010). Where children believe they have significant influence over what they are writing, greater effort and persistence in written tasks is also observed (Marinak et al. 2012). A sense of control is accompanied by positive emotions related to selfdetermination and a sense of independence, self-sufficiency and competence (Putman and Walker 2010). Rog (2011) argues that providing choice of content and context for learning empowers children to become independent, which fosters a sense of authorship and confidence, motivating children to learn and grow in their writing.

The strategies employed by educators subtly communicate beliefs about their confidence in the child's capacity for independent learning (Bruning and Kauffman 2016). Teaching practices identified as more controlling, in which children have little access to making decisions, have been associated with lower self-determination and motivation (Nolen 2007). In addition, the range of strategies children have for writing independently and for managing challenging aspects of their writing have also been found to impact on their sense of control and consequently motivation (Bruning and Kauffman 2016; Schunk and Zimmerman 2007). Furthermore, Marinak et al. (2012) argue that what children learn as valuable skills and content for writing, are communicated through the feedback they receive and impacts what they will focus on during the writing process.

\section{Children's Views of the Purpose of Writing Tasks}

Self-efficacy and self-determination are mediated through the classroom context, prior experiences of writing and the purpose and nature of the writing task (Troia et al. 2012). Research suggests that writing tasks that communicate what literacy is, why it is important and what it can do, are central to motivation as children learn about the value of writing (Magnifico 2010; Putman and Walker 2010). Meaningful writing experiences have been identified as those with an authentic communicative function, shaped by purpose and audience (Mata 2011). Writing tasks have greater meaning when they are responsive and immediate to events relevant to the writer, and this purpose is amplified when the communicative intent is made clear, engaging children's interest (Bahlmann and Myers 2019; Barratt-Pugh 2007). Bruning and Kauffman (2016) suggest that authentic writing tasks in which children have a sense of ownership and control create motivation, as they give children the opportunity to express and refine their voice. In addition, Hiebert and Raphael (2013) argue that when children are engaged in tasks that have a communicative purpose they are more likely to derive a high level of interest, enjoyment and a sense of achievement. In contrast, Bingham et al. (2017) point out that when educators emphasise the codes of writing, at the expense of the communicative message, students will become overly focused on this aspect of their writing, interrupting their flow of ideas and ultimately demotivating them. Furthermore, writing tasks that are essentially about mastering the codes of writing provide little motivation for emergent writers (Hass Dyson 2010).

\section{Children's Perceptions as a Means of Informing Practice}

While research about the perceptions of children toward writing explores the views of primary and secondary children, few teacher-initiated projects have investigated the views of children in the emergent stage of writing, particularly in relation to motivation. There is increasing recognition of the importance of children's perspectives as a means of informing pedagogy as educators reflect on their beliefs and practices (Dockett et al. 2011; Fern and Kristinsdóttir 2011). Indeed, evidence from numerous studies exploring the perspectives of young children suggests considerable benefit to listening to children in order to enhance the context of learning, and that children's participation and input are vital to the ongoing reflective practice of educators (Harris and Mantakis 2013). Evidence indicates that young children demonstrate wisdom and authority when presenting views reflecting their own experiences and are capable of providing insight which is highly relevant to the teaching and learning process (Dockett et al. 2011; Ruscoe et al. 2018).

\section{Methodology}

The teachers adopted a sociocultural theoretical framework which suggests that "experience, knowledge, and learning are dependent on a child's environment, context, and interactions with others..." (Bingham et al. 2017, p.36), using child centred participatory methodology. The teachers believed that by exploring the children's views of writing, using the constructs of self-efficacy and self-determination in conjunction with children's understanding of the purpose of writing, they would begin to uncover children's motivation for writing. This would lead to insights about their pedagogical practices and ultimately more effective outcomes for their children. Thus, the teachers decided to explore the following questions though informal, but carefully constructed conversations with their children:

1. What are the children's attitudes towards writing?

2. What sense do children have of ownership and control of their writing?

3. What are the children's views of the purpose of writing? 
The teachers debated creating their own conversation questions, but after a literature search, decided to use a survey developed by Byrnes and Brown (2007) to identify young children's orientation to literacy which was piloted in a national six-year project, titled, "Young Learners' Project", funded by the Australian Research Council. The survey consists of four parts related to children's knowledge of concepts of print, perceptions of reading, and writing and literacy activities they enjoy. Part 3 of the survey "What do children think about writing?" aligned with the teachers' three major questions and would allow other teachers to use the same schedule and enable comparison between studies. The following questions were taken from Part 3 of the survey, with permission from Byrnes and Brown (2007):

1. What are the children's attitudes towards writing?

- Do you like writing or having a go at writing things? (Yes, no, not sure).

- Do you think you are good at writing? (Yes, no, not sure).

- Do you think learning to write is easy? (Yes, no, not sure). Why do you think that?

2. What sense do children have of ownership and control of their writing?

- Do you like to choose the things you write? (Yes, no, not sure).

- Do you need to do anything special to help yourself learn to write? (Yes, no, not sure). Can you describe the things you do?

- What do you do when writing gets hard? Can you describe the things you do?

3. What are the children's views of the purpose of writing?

- Do you think it's a good idea to learn to write? (Yes, no, not sure). Can you tell me why do you think this?

- What kinds of things can you write?

- What kinds of things do you like to write?

Out of the nine questions, three required the children to respond with "yes", "no" or "not sure". The six remaining questions were expanded to give children the opportunity to provide further detail and three of these included an initial response of "yes", "no" or "not sure". This gave the teachers both quantitative and qualitative data to explore. The analysis of this data is described in the following section.

\section{Classroom Context}

The four pre-primary classes were located in the metropolitan area of Perth City. Two were identified as having high socio-economic status and two as having middle socioeconomic status (Australian Bureau of Statistics SocioEconomic Indexes for Areas 2016). At the beginning of the professional learning program the teachers were asked to described the key features of their writing program. In Western Australia, the pre-primary literacy curriculum is informed by the Western Australian Curriculum and Assessment Outline (School Curriculum and Standards Authority 2019). Writing includes creating short texts using beginning concepts about print, sound-letter and word knowledge and punctuation, and adopting correct posture and pencil grip, as well as participating in shared editing of students' own texts for meaning, spelling, capital letters and full stops (School Curriculum and Standards Authority 2019). The teachers described their children as being in the emergent stage of writing, which is defined as a period of developing understanding of the way in which writing is used as a means of communication, in conjunction with the codes of written language, including phonological awareness, alphabetic knowledge, concepts about print, word recognition, spelling patterns, and handwriting and punctuation (Hall 2010). The teachers described their program as providing a strong foundation in the codes of writing, involving daily writing lessons, based on explicit teaching involving the whole class. These were teacher directed and interactive, often with children gathered around an interactive whiteboard on the mat or siting at tables of five or six children. Lessons included modelling, scaffolding, copying, and completing the sentence exercises, such as "On the weekend, I ........". Following the lesson, children completed writing tasks independently and were encouraged to "have-a-go at spelling" by "sounding out the letters" and using the environmental print which included word walls, alphabet posters and word and/or letter of the week charts. The teachers acknowledged the importance of the communicative function, but felt the need to focus on the codes of writing as a foundation for being able to write for a communicative purpose.

\section{Participants}

Given the range of attitudes and practices identified by the teachers in relation to writing, the teachers decided that by eliciting perceptions from all the children they might gain further insights into children's motivation to write. In addition, they did not want to single-out individual children who already appeared to be lacking in enthusiasm for writing. Thus, they decided to talk with all of their pre-primary 
children. A total of 109 pre-primary children (46 girls and 63 boys) aged between five and five years six months took part in an informal conversation with their pre-primary teacher, in their classroom, about their views of writing. The data was collected over a five-week period in Term 2, when the children had attended pre-primary for approximately one term (10 weeks). Each teacher decided to talk with one child at a time, in the familiar context of the classroom. The conversations were presented to the children as a means of jointly investigating views of writing so that writing could be better supported. The teachers decided it would be too onerous to audio record and transcribe each conversation, so they used a hard copy of the questions for each child and wrote the child's responses under each question. The conversation took between ten and twenty minutes. The teachers were mindful of each child's response, (particularly those children who appeared to be reluctant writers) and used alternative sentences to enable each child to fully understand the questions. If a child appeared to become uncomfortable or disinterested, the teacher completed the interview at a later time or abandoned it altogether. Interestingly, the teachers reported that the majority of children were enthusiastic about taking part in the conversation and all children completed the interview.

\section{Data Analysis}

As a result of the large amount of data collected from the conversations, the learning facilitators from ECU entered both the qualitative and quantitative data into Qualtrics, a survey tool to help analyse data (Qualtrics 2005). The quantitative data, (responses to the closed questions) were disaggregated according to gender, as a means of identifying differences between girls and boys, entered individually, summarised and displayed as statistical summaries, in the form of tables. The qualitative data, that is the children's comments elicited from the open-ended questions, were again differentiated according to gender and written under the associated question in Qualtrics. Although Qualtrics is not used to code comments, this gave the teachers easy access to the children's comments and corresponding results of the closed questions. The comments were thematically analysed by employing the phases of analysis outlined by Braun and Clarke (2006). The phases involved reading and re-reading the children's comments in relation to each question, noting down initial categories and collating these into themes aligned with the three research questions. The learning facilitators worked with the four pre-primary teachers to identify and compare the themes from each classroom data set and discuss the findings across the qualitative and quantitative data.
The most difficult set of children's responses to categorise came from the final two questions in which children were asked "what they could write" and "what they liked to write". The teachers identified a difference between responses that related to writing individual words and responses indicating a topic or genre. Although not always easily differentiated, the teacher's knowledge of the child, the response and subsequent conversation helped to make this distinction. The following examples help to illustrate this distinction. Responses classified as aspects of the codes of writing included: a sentence indicating a single word, "I can write "mum", single named words "my, and, the", sounded out words "s-u-n", single sounds, or simply "words". Responses classified as a topic or genre included: the preposition "about", "about my new puppy", a plural indicator "dinosaurs, butterflies", or a specific genre, "stories, books, birthday cards".

\section{Findings}

The teachers explored the data to consider individual children, trends in whole class responses and similarities and differences across the four pre-primary classes. The findings from each class were very similar and these are presented under each research question, creating an overview of the perceptions of writing from all 109 children. The number of comments do not add up to the total number of girl and boys, because some children made several comments in response to a single question and these were counted separately. Quotes from the children are included in the following sections to illustrate children's responses: " $\mathrm{g}$ " indicates a response from a girl and " $b$ " indicates a response from a boy.

\section{Q1. What are the Children's Attitudes Towards Writing?}

\section{Most Children Liked Writing, Believe They are Good at Writing and that Writing is an Easy Task}

In contrast to the concerns identified by the teachers at the beginning of this project, the majority of children (91\%) indicated that they liked writing. This contrast may be somewhat explained by the finding that $100 \%$ of girls liked writing, while only $85 \%$ of boys held this view, with $15 \%$ giving a resounding "no" in answer to the question "Do you like writing or having a go at writing?". Even though $15 \%$ of boys did not like writing, $90 \%$ of boys and all girls, believed they were good at writing, however, again $10 \%$ of boys indicated they were "not good" or "not sure". Almost all girls (87\%) and two thirds of boys thought the process of learning to write was an easy task. Out of 78 comments about why writing was easy (40 girls and 38 
boys) both boys and girls gave responses that suggest that they were confident in their approach to writing tasks. For example, over a third of girls and almost $20 \%$ of boys explained that they "try hard", "learn", "remember" and "think" and almost a third of boys stated that writing "is easy" or that they "know how to do it" or simply that "I just do it". A similar number of girls (22\%) and boys (18\%) mentioned that because they could write words, write letters, and match letters to sounds, writing was easy, "because I learn the alphabet" (g), "because I am good at letters" (b) and "because I can spell" (g). A further $22 \%$ of girls and $12 \%$ of boys explained that learning to write was easy because someone helped them or provided something to copy. A group of children (14\% girls and 3\% boys) explained that learning to write was easy because they practiced and $5 \%$ of girls and boys explained that writing was "fun". Eight percent of boys related writing to reading, "easy "cos helps... me to read" (b) and a few children mentioned that writing was easy because they could correct mistakes, "because I can rub it off' (b).

\section{A Small Group of Children did not Like Writing and Felt Learning to Write was Hard}

Out of the $22 \%$ of children who believed learning to write was not easy, $77 \%$ were boys compared to $23 \%$ of girls, including one boy who was "not sure". Altogether they made 26 comments ( 3 girls and 23 boys) which suggests they were not confident in their approach to writing tasks. Comments that included the amount of time and effort that writing demanded came from boys (38\%), "because it takes a long time to write" (b) and the cognitive load, "because it's hard to spell words" (b) and "hard to think" (b). One of the girls and $12 \%$ of boys suggested that they made, or might make mistakes, and this inhibited them and made writing hard, "Because you might mess up a letter" (b). Just over ten percent of boys reported that they were still learning or had not learned to write, and therefore, they felt they were struggling, mentioning their lack of competence around the codes of writing, "I haven't learned to write words" (b) and "because it's hard to spell words" (b). Three boys and one girl simply stated that they just could not write, explaining, "I'm just not good yet" (b) and "I can't write by myself". A further two boys mentioned left-handedness as a potential impediment to learning to write. The physical difficulty of writing was also mentioned by one girl and two boys, "My fingers get lost... with the pencil and it gets bendy" (g). The remaining comments from the boys were about writing being hard because they could not read.

\section{Q2. What Sense Do Children Have of Ownership and Control of Their Writing?}

\section{Most Children Liked to Choose the Things They Write and Had Developed Strategies to Support Their Writing}

The majority of children reported that they like to choose the things they write $(95 \%)$, however, a small number of both boys (3\%) and girls (2\%) indicated that they did not like to choose or were "not sure" (boys $2 \%$, girls 4\%). Both girls and boys identified a number of strategies to support their writing in general and help them when writing became hard, suggesting a developing sense of control. Perhaps it is not surprising that the strategies the children mentioned for both supporting their writing and helping them when writing became hard were the same. Out of 196 comments combining supporting and helping strategies (87 girls and 109 boys) almost a quarter of boys and $15 \%$ of girls mentioned some form of general cognitive strategy, "I think and then I get it" (g), "sometimes I have to really concentrate so I don't end up with scribbles" (g), "listen to teachers when they are explaining" (b), "be quiet and watch" (b) and "I just have to try hard" (b). Over a quarter of girls and 18\% of boys talked about specific strategies related to the codes of writing. These included reference to sound-letter relationships, "Say the sounds then put them together to say the words" (b), "I have to learn the sounds of letters" (g), learning sight words, "I learn from my sight words" (g), and letters of the alphabet "learn my A B C" (b). Both girls (15\%) and boys (9\%) mentioned practicing as a strategy, often related to ongoing practice, "I practice all the days, after school, on weekends and holidays" (g), and the place of practice "I practice at home, in my room, by myself" (b), and with support "I practice at home, my brother helps me practice" $(\mathrm{g})$. The nature of practicing was also mentioned by some children in relation to the codes of writing, "practice sounding out..." (g) and "I spell the letters and practice my sight words" (g). Comments related to strategies to support the physical aspects of writing particularly in relation to pencil grip, were also included by $20 \%$ girls and $11 \%$ of boys. These comments ranged from simply holding the pencil correctly, to holding the pencil correctly in order not to damage the paper, "perfect pencil grip and don't tear the paper" (b) and supporting letter formation "perfect pencil grip, because " $\mathrm{t}$ " starts in the middle of the sky" (g).

In addition to the strategies identified above, four strategies were mentioned mainly in relation to when writing became hard. Asking for help was mentioned by a small number of girls and $15 \%$ of boys. When children extended their comments about asking for help, this was always related to the codes of writing, "I ask the grown up the letter" (b). Eight percent of girls and $6 \%$ of boys mentioned copying as a strategy in relation to home and school, "I have to copy what my brother 
writes" (b) and "I copy Mrs [teacher] words on the whiteboard" (g). In addition, a small number of children indicated that correcting their writing was an important strategy, "I can cross it out and make it good" (b) and two boys commented that when writing became hard someone would tell them what to write. Interestingly the same two girls and two boys simply indicated that they did not know what to do, and five percent of girls and $13 \%$ of boys made general comments which did not relate to either question about strategies for supporting their writing and helping them when writing became hard.

\section{Q3. What are the Children's Views of the Purpose of Writing?}

\section{Children Believe Learning to Write is Important}

As a whole group, the children unanimously agreed that learning to write was important and a good idea (99\%). Girls and boys identified the same reasons about the importance of learning to write in their 132 comments (59 girls and 73 boys). However, one boy explicitly stated that he did not like to write and two boys commented that they did not know why learning to write might be important.

Learning to write was identified as a means of supporting reading by over a quarter of both girls and boys, followed by comments about the importance of writing as a means of helping to learn to write letters, sounds and words $(25 \%$ girls and 23\% boys); "because we can learn and know all the letters" (b) and "It helps you learn sounds and other words" $(\mathrm{g})$. This was followed by general comments about becoming more proficient and independent writers and supporting learning in general (23\% girls and $30 \%$ boys); "so we can get better at writing" (b), "because I want to write by myself" (g) and "because I like writing better, it helps me to learn" (g). Girls (20\%) and boys (14\%) also mentioned the importance of writing for a future purpose, "because you get to go to Year 1 and you be a best reader" (b) and "because then you will know how to write words when you grow up" (g). In addition, six comments seemed to suggest that the purpose of writing was to ensure the presentation of writing was correct, so it would be "neat" (g) and "perfect" (b \& g) and not "messy" (b). Only three children (two girls and one boy) mentioned the importance of writing for a specific communicative purpose, which included, "because you can write letters to people" (b), "because I want to write a story" $(\mathrm{g})$ and "because then you can write something ....like for a birthday" (g).

\section{Children's Views of What they Could Write Mainly Related to the Codes of Writing}

Out of 113 comments (52 girls and 61 boys) about what they could write, over half of both girls (57\%) and boys (58\%) related to the codes of writing. Comments related to sounds and words included general comments such as, "tricky words", "hard words", "sight words", "letters", "alphabet", and specific words (e.g., "I know how to write words like 'said', letter 'c', capital letters" (b). A small number of boys $(8 \%)$ and girls $(8 \%)$ mentioned they could write a "sentence".

Topics of interest and specific genres were mentioned by a third of girls and 19\% of boys. Topics of interest did not include a form of writing, children simply named their topic of interest, "dinosaurs, butterflies" (g) and "I like to write about Star Wars" (b). In relation to specific genres of writing, a general comment about writing stories and / or books was made by $20 \%$ of girls and $6 \%$ of boys. One girl explained her idea for a story, "a story about the last rainbow" (g) and two girls and two boys expanded on their idea for a book, "a book about fairies" (g) and "a car book with you" (b). In addition, one boy and four girls mentioned other purposes for writing, including cards, birthday cards, notes and letter to a friend or relative, "birthday cards and love notes" (g), "a letter to my Aunty" (g) and "I can write mum's shopping list" (b). A small number of both boys (9\%) and girls (9\%) mentioned writing their own name or names of their family or pets. However, $6 \%$ of boys commented that they did not know what they could write, and $7 \%$ of boys made unrelated comments.

\section{Children's Views of What They Liked to Write Related Mainly to Topics or Genres}

When asked if there was something they liked to write, $90 \%$ of girls and $85 \%$ of boys said "yes" and altogether 116 comments were made (52 girls, 64 boys). Interestingly, comments about the codes of writing dropped dramatically, only $5 \%$ of girls and $7 \%$ of boys commented on these aspects of writing. Almost half of the girls (46\%) and over half of the boys (54\%) commented on topics of interest and /or specific genres. Topics of interest included further explanation by some children, "the things I like... Spiderman, Lightening McQueen" (b) and "my favourite things... butterflies, rainbows and flowers" (g) and more personal topics, "I like to write about places [I've been] and my family" (b).

In relation to specific genres, writing stories was mentioned by two girls and one boy, who also gave an explanation, "I like to write short stories because it's easy to write" (b). All other comments related to the purpose and sometimes audience, and included writing notes and cards, "I like to write my family notes and I tell myself it's good to write" (g) and 'birthday cards, going to party cards' (g). Interestingly, boys exclusively mentioned practical purposes such as lists and maps, "to sign papers" (b) and "to work, to buy things" (b), whereas girls exclusively suggested writing of a more personal nature, including cards and letters. 
In addition, $38 \%$ of girls and $23 \%$ of boys indicted that they liked writing their name, often adding an explanation, "my name on the birthday card because people will know who give them the card' (g), "I like to write my name when I'm drawing a picture" (g), and "My name, 'coz I love writing my name. Sometimes I try to teach my sister how to write her name" (b). Writing for specific people or events was also mentioned by a few children, "my sister's birthday" (b), "writing something for Ellie" (b) and "things for other people" $(\mathrm{g})$. However, $15 \%$ of boys and $10 \%$ of girls indicated that there was nothing they particularly liked to write about.

\section{Reflections on the Findings}

The teachers felt that the time and effort involved in collecting, analysing, and sharing the wealth of information about children's attitudes towards writing, ownership and control, and understanding of the purpose of writing had given them deep insights into the children's motivation to write. They recognised the need to interpret the children's comments with caution and substantiate their findings with additional evidence, but overall, they acknowledged that the majority of children had a positive attitude to writing. Most children appeared to be learning to write with optimism, suggesting a developing sense of self-efficacy which is integral to motivation (Bruning and Kauffman 2016; Marinak et al. 2012; Mata 2011). Almost all of the children who liked writing also thought writing was easy to learn, offering a number of reasons which were related to ways of improving their writing as well as seeing themselves as "good" writers. They were confident in their approach to writing, indicating a sense of self-determination, whereby they have some control and ownership over the writing process. This was particularly evident in relation to their identification of strategies to master the codes of writing and their desire to choose their topic of writing, suggesting some level of developing independence (Pajares and Valiante 2006). However, while recognising these positive aspects of writing, the teachers identified four key issues, that had important implications for their practice.

Lack of Motivation. Their concerns about children who appeared to lack motivation identified at the beginning of the project, were substantiated particularly in relation to a small group of boys and to a lesser extent girls. These children indicated that they did not like writing (15\% boys) or were not good at writing (10\% boys), that writing was not easy (33\% boys, $13 \%$ girls), that they were not able to identify strategies to support writing or for when writing became hard (15\% boys, 7\% girls), did not know what they could write ( $6 \%$ boys), and had nothing they particularly liked to write about (15\% boys, $10 \%$ girls). In addition, these children often made unrelated comments or simply stated that they "did not know". Although these aspects do not necessarily reflect a negative attitude, their associated comments, particularly in relation to boys, suggest $a$ sense of disengagement in the writing process. Although there are a limited number of studies conducted in the early years of schooling, evidence suggests that there are gender differences in relation to writing (Adams and Simmons 2019) which include girls having a more positive attitude to writing than boys (Graham et al. 2007) and evidence from the later years suggests that boys report "poorer outcomes on several important motivation and engagement constructs" (Collie et al. 2015 p.774). This difference may contribute to the lower achievements of boys evidenced in national assessments (Cobb-Clark and Moschion 2015; OECD 2015; Reilly 2018). Although gender differences are complex and multifaceted, Pajares and Valiante (2006) argue that in many schools writing is viewed as a "female-domain" (p150) and this influences self-efficacy and self-determination particularly in relation to boys. They argue that educators must ensure that their literacy programs are "perceived as relevant and valuable both to girls and boys" (p.151). The teachers explained that they had not differentiated their writing program in relation to gender. They had not realised the extent of apparent confusion and disengagement of these children and had simply considered them to be in the early stages of writing, "finding their feet" as writers.

In addition to concern about a particular group of boys the teachers were puzzled about the contrast between the majority of children who reported that they liked writing and their observations that many children appeared to lack motivation at times during writing lessons. This may be explained in part by the recognition of the value placed on a task by the teacher (learning the codes of writing), and their desire to please the teacher and complete the task to a satisfactory level, even though they may not be very enthusiastic or engaged (Håland et al. 2019).

Emphasis on the Codes of Writing: The majority of children were developing a sense of control of the codes of writing, evidenced in their comments about the strategies they used to support their writing and when writing became hard. The strategies clustered around general cognitive strategies, learning the codes of writing, practicing the codes of writing, copying words, and seeking adult guidance on what to write, which often had an emphasis on sounds, letters, and words. Although the children were developing some control of the codes of writing, which is linked to independence and increasing competence (Putman and Walker 2010; Rog 2011), there seemed to be little expectation of engaging in the thinking needed to generate a text with a purpose and audience. On reflection, the teachers acknowledged that these strategies echoed their focus during writing activities and feedback, which influence what children value and focus on their writing (Marinak et al. 2012). In addition, although 
the majority of children indicated that they liked to choose what to write, thereby having some sense of ownership, the teachers reflected that they provided limited opportunities for their children to initiate writing and develop their own texts, potentially impacting on their sense of ownership and ultimately motivation (Hidi and Boscolo 2008; Magnifico 2010; Nolen 2007).

Limited View of the Importance of Writing as a Means of Communication: The majority of children had a strong sense of why learning to write is important, suggesting some understanding of what writing can do, potentially enhancing motivation (Magnifico 2010; Mata 2011; Putman and Walker 2010). They believed that writing is important in relation to other literacy components (reading), as a means of improving their understanding of writing codes and presentation, supporting learning in general and for a future purpose. However, very few comments related to the communicative purpose of writing, a key motivational component (Bahlmann and Myers 2019; Bruning and Kauffman 2016; Hiebert and Raphael 2013). This reflected the teachers' informal and regular comments about the importance of writing, particularly its connection to reading, but with little reference to the purposes of writing.

Lack of Confidence in Writing for Communitive Purposes: The children's perceptions of what they could write and what they liked to write differed markedly. Over half of the children's responses to what they could write, related solely to the codes of writing. Although topics and genres were mentioned, very few children elaborated on their response simply giving one word answers and only five children mentioned the communicative purpose of their writing. This was in contrast to their view of what they liked to write in which almost half the children mentioned specific genres or purposes. This suggests that many of the children recognised the communicative function of writing but conceptualised their competency in terms of their coding skills. The teachers recognised that although they introduced children to some purposes for writing, such as a report about "What I did on the weekend ...", their emphasis tended to be on the codes of writing rather than purpose and audience.

\section{Changing Practice}

Evidence suggests that the children's motivation for writing was complex, multifaceted, and interrelated, involving attitudes and beliefs, a sense of ownership and control, and perceptions of the importance and value of writing. Although all three constructs are important, children's perceptions of writing as means of communicating for different purposes and audiences has been identified as one of the most significant aspects of motivation (Mata 2011). Mata argues that participation in authentic literacy situations that engage children's interests, is fundamental to their developing competence as writers and the value they attach to literacy (Mata 2011). Thus, the teachers recognised that although the majority of children appeared to be motivated, ultimately an emphasis on the cognitive knowledge and skills of writing with little attention to the communicative purposes risked de-motivating the children. In addition, the emphasis on the codes of writing may have exasperated the apparent lack of motivation some children reported (boys in particular), further undermining their beliefs about themselves as writers. While acknowledging the importance of the codes of writing, the teachers began to think about the fundamental purpose of writing as a means of communication, embedded in the children's experiences and interests, mediated through the sociocultural contexts of their everyday lives. These reflections helped the teachers to re-think the following fundamental aspects of their writing program.

Providing a Variety of Writing Experiences That Have an Authentic Purpose and Audience: Placing the communicative function of writing at the centre of their writing program, created opportunities for the children to reframe their perceptions of writing from a series of codes to be "cracked", to a meaningful and powerful activity, enhancing both self-efficacy and self-determination (Bruning and Kauffman 2016; Magnifico 2010; Putman and Walker 2010). This included integrating writing into curriculum areas, incorporating writing into structured play, publishing books, and encouraging children to initiate their own ideas based on their interests, while simultaneously supporting the codes of writing both implicitly and explicitly through intentional teaching (Bahlmann and Myers 2019). Although still in the early stages of development, the teachers described some of the changes they made and the associated outcomes:

That was very motivating for them. Making an actual book, they're... "This is my first book! I'm an author! I've published my first book!' When the ... more reluctant ones saw the other children ... how special the book was when it was put there [on display]... it was a chain reaction!

When we did the space centre, when we do the supermarket, or when we did a hairdresser... they have to write that it's a space centre and what they'll see in the space centre. They need to create the computer... In the supermarket they need to write where the dairy is going to stay, where the vegies are staying. They need to label everything.

I have consciously thought about why they're writing it and who's going to be reading it. So, a lot of the things that they have been doing, I've consciously thought of the audience more than I used to. So, writing has become a lot more purposeful. 
Providing Feedback on Content, Purpose and Audience: Providing feedback that indicated how much the teachers valued children's ideas was aimed at giving children a sense of ownership (Marinak et al. 2012). By talking with their children about the content, purpose, and audience they indicated what was important and how they could make their message more effective (Gerde et al. 2012). They used feedback that highlighted the concepts of purpose and audience through modelled writing, as well as scaffolded children's work and provided strategies for thinking about ways of addressing an audience and providing appropriate content. They encouraged children to share their writing, to gain feedback and write to authors about their processes of writing (Jalongo 2014). All four teachers made a deliberate decision to focus on meaning when providing feedback, with positive results:

I've stopped correcting their work. I have started having conversations with them....and what actually happened was the children realised I respected their work .... They started writing more, they started writing all over the classroom.

I started off by focusing on capital letters, full stops, sounding out words and looking at the techniques of writing and in no time at all the children were feeling bad about themselves. "I can't do it." And they'd come to me straight away for, "How do I spell this?" because they knew that there was one way to spell it and so actually my scaffolding was hindering them... So I thought, right. I'm going to focus on their ideas, praise and encourage... and I went on from that and they have just blossomed.

Rather than worrying so much about whether they're forming the letters just so, and the technique aspect of it, and become much more focused on looking for meaning and looking for that, that pure motivation which is where the writing is really coming from... something that they want to tell me or tell each other... genuine communication.

Being Aware of Children Who Appeared to be Struggling: The teachers were concerned about the relatively high number of boys that appeared to be struggling with writing. This prompted the teachers to think about where writing takes place, the writing topics, and the connection between home and school, as a means of creating writing opportunities that are relevant to girls and boys (Pajares and Valiante 2006). The teachers also agreed that it was important to engage in intentional teaching and talk to the children about the process of writing, by being explicit about what they were learning about becoming independent authors, and how to access and use strategies to develop their authorship (Bahlmann and Myers 2019). Rather than differentiate the curriculum on the basis of gender, the teachers increased writing spaces and included well equipped outdoor writing areas, writing implements for the sand and water area, observed and talked with children about their interests and explained the purpose of specific writing input. They encouraged children to work together and articulate and plan for the purpose and audience of their writing. Interestingly, a much broader range of writing topics began to emerge. These included labelling, instructions, letters, non-fiction books, maps, creating a sports team, and explaining rules of a game. One teacher described what happened when she changed the context of writing:

This week I've put stuff outside ... I made a new area where we could have some writing tables and put some umbrellas up and things, and ... even the boys who play footy were over there all morning writing... it was owned by the boys, they sat there all day. When they weren't doing something else they went straight back to it ... there was about five boys and they were writing all sorts of things... the boys did this whole planning thing together.

\section{Conclusion}

In summary, the child centred participatory nature of the research informed by a sociocultural theoretical framework enabled the teachers to consider their pedagogy in relation to children's perceptions of writing. The collaborative nature of the project helped the teachers act as critical friends as they re-conceptualized their understanding of emergent writing and the relationship between motivation and writing. This led to significant changes in their writing programs, centered around meaningful writing opportunities while continuing to support children's understanding of the codes of writing. Early reflections on these innovations provided some evidence of increased motivation. This project has the potential to be duplicated across early childhood classrooms, enabling teachers to gain insights into the impact of their pedagogical practices on children's motivation, informed by children's perceptions. Finally, developing ways of listening to children and working in collaboration with other teachers has implications for improving outcomes for children not only in writing but as a means of learning and teaching in other curriculum areas.

Acknowledgement We would like to thank the Association for Independent Schools Western Australia (AISWA) for funding this project and in particular Ron Gorman, Deputy Director of AISWA for his ongoing and absolute commitment to collaborative professional learning. We acknowledge the schools who released the teachers to take part in the program and thank Anne Hey and Julie Broz from AIWSA for sharing their knowledge and experience in creating and implementing the program. We are indebted to the teachers for their bravery and honesty in reflecting on their practice in order to improve outcomes 
for their children and sharing this with us and each other. Finally, we thank the children for their willingness to describe their perceptions of writing with such clarity and enthusiasm. We hope this is the beginning of a long and successful journey.

\section{Compliance with Ethical Standards}

Ethical Approval All procedures performed in studies involving human participants were in accordance with the ethical standards of the institutional research committee (Edith Cowan University Human Research Committee, number9439) and the Australian Government National Statement on Ethical Conduct in Human Research (2007-Update 2018).

Open Access This article is licensed under a Creative Commons Attribution 4.0 International License, which permits use, sharing, adaptation, distribution and reproduction in any medium or format, as long as you give appropriate credit to the original author(s) and the source, provide a link to the Creative Commons licence, and indicate if changes were made. The images or other third party material in this article are included in the article's Creative Commons licence, unless indicated otherwise in a credit line to the material. If material is not included in the article's Creative Commons licence and your intended use is not permitted by statutory regulation or exceeds the permitted use, you will need to obtain permission directly from the copyright holder. To view a copy of this licence, visit http://creativecommons.org/licenses/by/4.0/.

\section{References}

Adams, A. M., \& Simmons, F. R. (2019). Exploring individual and gender differences in early writing performance. Reading and Writing, 32(2), 235-263. https://doi.org/10.1007/s11145-018-9859-0.

Australian Bureau of Statistics (2016). Western Australia: Regional data summary. Retrieved 13 Nov 2018 from: https://quickstats .censusdata.abs.gov.au/census_services/getproduct/census/2016/ quickstat/5?opendocument.

Bandura, A. (1977). Self-efficacy: Toward a unifying theory of behavioral change. Psychological Review, 84(2), 191-215. https://doi. org/10.1037/0033-295X.84.2.191.

Bahlmann B. C. M., \& Myers, J. K. (2019). Young children's writing in play-based classrooms. Early Childhood Education Journal, 2(48), 233-242. https://doi.org/10.1007/s10643-019-00990-0.

Barratt-Pugh, C. (2007). Multiple ways of making meaning: Children as writers. In L. Makin, C. Jones-Diaz, \& C. McLachlan (Eds.), Literacies in childhood: changing views, challenging practice (pp. 133-152). NSW: MacLennan \& Petty.

Bingham, G. E., Quinn, M., \& Gerde, H. K. (2017). Examining early childhood teachers' writing practices: Associations between pedagogical supports and children's writing skills. Early Childhood Research Quarterly, 39, 35-46. https://doi.org/10.1016/j.ecres q.2017.01.002.

Bogner, K., Raphael, L., \& Pressley, M. (2002). How Grade 1 teachers motivate literate activity by their students. Scientific Studies of Reading, 6(2), 135-165.

Boscolo, P., \& Hidi, S. (2007). The multiple meanings of motivation to write. In G. Rijlaarsdam (Series Ed.) and P. Boscolo \& S. Hidi (Volume Eds.), Studies in Writing. Vol. 19, Writing and Motivation (pp.1-14). Oxford: Elsevier.

Braun, V., \& Clarke, V. (2006). Using thematic analysis in psychology. Qualitative Research in Psychology, 3(2), 77-101.
Brown, C. P., \& Englehardt, J. (2016). Conceptions of and early childhood educators' experiences in early childhood professional development programs: A qualitative metasynthesis. Journal of Early Childhood Teacher Education, 37(30), 216-244. https://doi. org/10.1080/10901027.2016.1204574.

Bruning, R., \& Kauffman, D. (2016). Self-Efficacy Beliefs and Motivation in Writing Development. In C. MacArthur, S. Graham, \& J. Fitzgerald (Eds.), Handbook of Writing Research (Vol. 2, pp. 160-173). New York: The Guilford Press.

Byrnes, L. J., \& Brown, P. M. (2007). ORIENT: A scale to measure children's orientation to literacy: Interview schedule. Melbourne: The University of Melbourne.

Cobb-Clark, D., \& Moschion, J. (2015). Gender Gaps in Early Educational Achievement (Working Paper No. 23/15). Retrieved 10.2.2020 from Faculty of Business and Economics: University of Melbourne website: https://www.melbourneinstitute.com/ downloads/working_paper_series/wp2015n23.pdf

Collie, R., Martin, A., \& Curwood, J. (2015). Multidimensional motivation and engagement for writing: Construct validation with a sample of boys. Educational Psychology, 36(4), 771791. https://doi.org/10.1080/01443410.2015.1093607.

Dockett, S., Einarsdottir, J., \& Perry, B. (2011). Balancing methodologies and methods in researching with young children. In D. Harcourt, B. Perry, \& T. Waller (Eds.), Researching young children's perspectives: Ethics, theory, and research (pp. 68-81). London: Routledge.

Fern, E., \& Kristinsdóttir, G. (2011). Young people act as consultants in child-directed research: an action research study in Iceland. Child \& Family Social Work, 16(3), 287-297. https://doi.org/1 0.1111/j.1365-2206.2010.00740.x.

Graham, S., Berninger, V., \& Fan, W. (2007). The structural relationship between writing attitude and writing achievement in first and third grade students. Contemporary Educational Psychology, 32(3), 516-536.

Grainger, T., Gouch, K., \& Lambirth, A. (2003). 'Playing the game called writing': Children's views and voices. English in Education, 37(2), 4-15.

Gerde, H. K., Bingham, G. E., \& Wasik, B. A. (2012). Writing in early childhood classrooms: Guidance for best practices. Early Childhood Education Journal, 40(6), 351-359.

Hall, K. (2010). Effective literacy teaching in the early years of school: A review of evidence. In J. Larson \& J. Marsh (Eds.), Handbook of early childhood literacy (pp. 523-540). London, UK: Sage.

Håland, A., Hoem, T. F., \& McTigue, E. M. (2019). Writing in first grade: The quantity and quality of practices in norwegian classrooms. Early Childhood Education Journal, 1(47), 63-74.

Harris, P., \& Mantakis, H. (2013). Children's voices: A principles framework for children and young people's participation as valued citizens and learners. Adelaide: South Australian Department for Education and Child Development.

Hass Dyson, A. (2010). The place of childhoods in school writing programs: A matter of ethics. In J. Larson \& J. Marsh (Eds.), Handbook of early childhood literacy (pp. 485-500). London, UK: Sage.

Hiebert, E. H., \& Raphael, T. E. (2013). Early literacy instruction (reprint of 1998 ed.). Santa Cruz: Text Project Inc.

Hidi, S., \& Boscolo, P. (2008). Motivation and writing. In C. A. MacArthur, S. Graham, \& J. Fitzgerald (Eds.), Handbook of writing research (pp. 144-157). New York: The Guilford Press.

Hidi, S., \& Renninger, K. A. (2006). The four-phase model of interest development. Educational Psychologist, 41(2), 111-127.

Jalongo, M. R. (2014). Early Childhood Language Arts (6th ed.). London, UK: Pearson.

Kissel, B. T., \& Miller, E. T. (2015). Reclaiming power in the writers' workshop: Defending curricula, countering narratives, and 
changing identities in prekindergarten classrooms. The Reading Teacher, 69(1), 77-86.

Mackenzie, N. M., \& Petriwskyj, A. (2017). Understanding and supporting young writers: Opening the school gate. Australasian Journal of Early Childhood, 42(2), 78-87.

Magnifico, A. M. (2010). Writing for whom? Cognition, motivation, and a writer's audience. Educational Psychologist, 45(3), 167-184.

Marinak, B. A., Gambrell, A. B., \& Mazzoni, S. A. (2012). The teacher the text and the context as factors in motivating students to write: The motivation to write scale in maximizing motivation for literacy learning. New York: Guilford Publications.

Mata, L. (2011). Motivation for reading and writing in kindergarten children. Reading Psychology, 32(3), 272-299.

Nolen, S. B. (2007). Young children's motivation to read and write: development in social contexts. Cognition and Instruction, 25(23), 219-270.

OECD. (2015). The ABC of gender equality in education: Aptitude, behaviour, confidence, PISA. Paris: OECD publishing.

Opfer, V. D., \& Pedder, D. (2011). Conceptualising teacher professional learning. Review of Educational Research, 81(3), 376-407.

Pajares, F., \& Valiante, G. (2006). Self-Efficacy Beliefs and Motivation in Writing Development. In C. A. MacArthur, S. Graham, \& J. Fitzgerald (Eds.), Handbook of writing research (pp. 158-170). New York: The Guilford Press.

Putman, M., \& Walker, C. (2010). Motivating children to read and write: using informal learning environments as contexts for literacy instruction. Journal of Research In Childhood Education, 24(2), 140-151. https://doi.org/10.1080/02568541003635243.

Qualtrics (2005). Qualtrics research suite (version21269). Provo, UT: Qualtrics Labs, Inc. Retrieved from https://www.qualtrics.com.

Reilly, D., Neumann, D., \& Andrews, G. (2018). Gender differences in reading and writing achievement: Evidence from the National Assessment of Educational Progress (NAEP). American Psychologist, 74(4), 1-7. https://doi.org/10.1037/amp0000356.
Rog, L. J. (2011). Read, write, play, learn: Literacy instruction in today's kindergarten. Newark, DE: International Reading Association.

Rueda, R. (2011). The 3 dimensions of improving student performance: Matching the right solutions to the right problems. New York: Teachers College Press.

Ruscoe, A., Barblett, L., \& Barratt-Pugh, C. (2018). Sharing power with children: repositioning children as agentic learners. Australasian Journal of Early Childhood, 43(3), 63-71. https://doi. org/10.23965/AJEC.43.3.07.

School Curriculum and Standards Authority (Government of Western Australia 2019). K-10 Outline. Retrieved from https://k10outline .scsa.wa.edu.au

Schunk, D. H., Pintrich, P. R., \& Meece, J. L. (2008). Motivation in education: theory, research, and applications (3rd ed.). Upper Saddle River, N.J.: Pearson/Merrill Prentice Hall.

Schunk, D. H., \& Zimmerman, B. J. (2007). Influencing children's self-efficacy and self-regulation of reading and writing through modeling. Reading and Writing Quarterly, 23(1), 7-25. https:// doi.org/10.1080/10573560600837578.

Troia, G. A., Shankland, R. K., \& Wolbers, K. A. (2012). Motivation research in writing: Theoretical and empirical considerations. Reading \& Writing Quarterly, 28(1), 5-28.

Wigfield, A., Eccles, J.S., Fredricks, J.A., Simpkins, S., Roeser, R.W., \& Schiefele, U. (2015). Development of achievement motivation and engagement. In M.E. Lamb \& R.M. Lerner (Eds.), Handbook of child psychology and developmental science: Vol. 3. Socioemotional processes (7th ed., pp. 657-700). Hoboken, NJ: John Wiley $\&$ Sons.

Publisher's Note Springer Nature remains neutral with regard to jurisdictional claims in published maps and institutional affiliations. 